OPEN ACCESS

Edited by:

Stefan Bouzarovski,

The University of Manchester,

United Kingdom

Reviewed by:

Kalle Kuusk,

Tallinn University of Technology, Estonia

Paula Femenias,

Chalmers University of

Technology, Sweden

${ }^{*}$ Correspondence:

Iñigo Antepara

inigo.antepara@ehu.eus

Specialty section: This article was submitted to Urban Energy End-Use,

a section of the journal

Frontiers in Sustainable Cities

Received: 29 November 2020

Accepted: 21 July 2021

Published: 16 August 2021

Citation:

Antepara I (2021) Under-Consumption Penalties in the Low Carbon Market: Reflections From a Spanish Social Housing Provider. Front. Sustain. Cities 3:635149. doi: 10.3389/frsc.2021.635149

\section{Under-Consumption Penalties in the Low Carbon Market: Reflections From a Spanish Social Housing Provider}

\author{
Iñigo Antepara* \\ Department of Economic Analysis, University of the Basque Country (UPV-EHU), Bilbao, Spain
}

This proposal focuses on the analysis of three case studies of a Spanish social landlord-Basque Alokabide, submitted to the Carbon Fund for a Sustainable Economy. The calculation of $\mathrm{CO}_{2}$ emissions follows the methodology recommended by the Spanish government. The economic viability of the cases analyzed is calculated, first without taking into account the money obtained from the carbon market, and then taking advantage of the sale of the emissions. The interest value of this work is the examination of how low incomes tend to be overrepresented in social housing, resulting in lower energy consumption and colder dwellings. Since low income tenants under-consume energy, before renovation $\mathrm{CO}_{2}$ emissions are lower, and therefore Alokabide is taking less advantage of the carbon market. Additionally, photovoltaic systems, while easier to implement even at district level, are not eligible in the Spanish program, and this is also disadvantageous. In the policy recommendations, the ex-ante accounting of emissions should be justified on the basis of theoretical energy consumption with average consumers, rather than verifying ex-post actual emissions by low income household that under consume: energy efficiency measures lead to improved thermal comfort, and this added benefit should be taken into account in the economic viability. Toward the goal of reducing emissions after retrofitting, decarbonization is more feasible than the reduction of the energy consumption through the substitution of fossil fuels by renewables to satisfy primary energy needs.

Keywords: low carbon, social housing, energy poverty, under-consumption, positive energy districts

\section{INTRODUCTION}

The issue of environmental sustainability and low carbon regulations are becoming increasingly relevant on the European agenda. The European Commission (2020) has proposed to cut net greenhouse gas emissions in the EU by a minimum of $55 \%$ by 2030 compared to 1990 . Through the Affordable Housing Initiative, the European Commission (2020) will give support to local social housing projects, including measures to protect social housing tenants against energy poverty (European Parliament, 2013).

For social housing, the good news is that they have more opportunities to implement energy efficiency (EE) measures (Walker, 2008), and therefore homes occupied by social renters tend to be more energy efficient than the general housing stock (Barnes and McKnight, 2014). Regarding 
energy districts, communities with district heating deal better with energy poverty by creating heat markets which enable fuel flexibility (Hathway, 2010).

Nevertheless, there is also less positive news; low income is overrepresented in social housing (Teli et al., 2016). In Spain, the consumption profile of tenants results in a lower usage of electricity and heating than an average household (Aranda et al., 2017). Jenkins et al. (2011) analyzed energy consumption in terms of carbon intensity in UK, resulting in lowest deciles of income consuming significantly less. When households are not spending enough to achieve a certain standard of energy services, Rademaekers et al. (2016) state that under-consumption occurs and, low-income householders often live under colder living conditions (Moore, 2012). Besides, due to the large deposit required in Positive Energy Districts, this represents a greater negative effect on those in social housing (Hearn et al., 2021).

In the literature of energy performance gap (Wilde, 2014), there is also space for these two situations frequently observed in social housing; the implementation of EE measures and lowincome energy consumers. For such cases, Sunikka Blank and Galvin (2012) introduced the "prebound" effect; the situation before a retrofit, and indicates how much less energy is consumed than expected. However, they found that the energy intensity after retrofit of houses of low-income households is closer to one.

This also has implications for reducing $\mathrm{CO}_{2}$ emissions from the social housing sector. Due to the "prebound" effect, Teli et al. (2016) showed the problem of achieving the anticipated carbon savings. As a result, compared to the able-to-pay, a greater EE improvement with higher costs is required in order to achieve the same carbon reduction (Rosenow et al., 2013). Moreover, Boardman (2013) emphasizes that low-carbon policies increase the energy bills when emissions are internalized, and the effect is disproportionately higher for marginalized groups.

This paper builds on earlier work for the social housing provider Alokabide. Hernández et al. (2019) performed an energy audit for the building stock of Alokabide stating its good energy performance and a lower-than-expected energy consumption by the tenants. Using a different methodology, Antepara et al. (2020) confirmed the observed energy under-consumption. Both studies draw a scenario similar to that described by Teli et al. (2016), the fuel poverty-induced "prebound effect."

Taking a step forward, the focus will be put on the accounting and selling of the carbon emissions of three different case studies of Alokabide. The methodology for the calculation of $\mathrm{CO}_{2}$ emissions is taken from the Carbon Fund for a Sustainable Economy (FES-CO $\mathrm{CO}_{2}$ ), managed by the Spanish Government. The article also includes a discussion of the results and some implications for policymakers, highlighting the key findings that show the negative outcomes of the carbon market when lowincome households are involved.

\section{RESEARCH METHOD}

Spanish social housing is considered to be a targeted model, which means that social landlords aim to satisfy only the excess of housing demand not satisfied by the market. Allocation is made according to a set of vulnerability indicators (European Parliament, 2013), particularly income, i.e., targeted and residual model. As a consequence, low income is overrepresented. While the contract with the tenants sets out the rent to be paid for the dwelling, other energy-related payments cannot be included.

In order to study the viability of improvements that seek decarbonization, the case of Alokabide-the Basque public company for public rental-is herein analyzed. After the energy audit performed for the building stock of Alokabide, Hernández et al. (2019) concluded that the tenants are under-consuming heating, i.e., the pre-bound effect described by Sunikka Blank and Galvin (2012), but not domestic hot water (DHW).

The estimation of emission reductions is based on data taken from the information submitted to the $\mathrm{FES}-\mathrm{CO}_{2}$ as a "Proyecto Clima" (Ministerio para la Transición Ecológica y el Reto Demográfico, 2019). Created by Law 2/2011 of Sustainable Economy, provides financial support to projects that reduce emissions in Spain by purchasing $\mathrm{CO}_{2}$ emissions reductions. Alokabide can only afford 1-2 investments per year, i.e., an insufficient annual renovation rate of around $1 \%$, and this is an opportunity to scale up these interventions. Two types of EE measures were taken into consideration: the production of DHW with solar heating, and the retrofitting of a whole building. Photovoltaic (PV) systems are not eligible in this program. The project was approved in January 2021. FES- $\mathrm{CO}_{2}$ will complete the corresponding payment once the emission reductions are verified.

First, the situation ex-ante will be described, i.e., the information and calculations included in the "Proyecto Clima," and then, based on the energy profile of the tenants at Alokabide, the expected ex-post situation-used to claim the money corresponding to the verified emissions to FES- $\mathrm{CO}_{2}$-will be anticipated.

\section{Fossil Fuels Substitution by Solar Thermal Energy}

The two solar installations for the production of DHW submitted to the FES- $\mathrm{CO}_{2}$ are described:

1) ZABALGANA 92. The first case analyzed is the replacement of the solar thermal panels in a building whose construction was prior to the Spanish Technical Code of Buildings (Código técnico de edificación, CTE) of 2006, and therefore does not have to comply with the minimum solar contribution of $30 \%$ of the DHW that is mandatory for projects after 2006. The multi-occupancy building comprises 92 dwellings in Vitoria-Gasteiz (Spain). Being one of the first solar thermal installations in the area, the installer failed to fix the systems correctly. Consequently, up to the time of replacement, the heating and DHW needs were covered only by the natural gas (NG) boiler. The solar panels were replaced by vacuum tubes.

2) ARRASATE 140. The second case analyzed is the replacement of the solar thermal panels in a building constructed after the CTE of 2006, which therefore had to comply with a minimum solar contribution of the $30 \%$ of the DHW. Consequently, only the computation of emissions reduction of the DHW produced exceeding this percentage is allowed. 
TABLE 1 | Data for NG used in the methodology.

\begin{tabular}{lccc}
\hline Density & $\begin{array}{c}\text { Low calorific } \\
\text { value } \\
\text { (LCV) (GJ/t) }\end{array}$ & $\begin{array}{c}\text { Total } \mathrm{CO}_{2} \\
\text { emission factor } \\
\text { (kg/GJ) }\end{array}$ \\
\hline Natural gas & 0,79 & 48,6 & 56 \\
\hline
\end{tabular}

The multi-occupancy building comprises 140 dwellings in Arrasate-Mondragon (Spain). Although the solar installation was relatively new, it never worked as projected due to lack of maintenance.

Within the methodologies proposed by $\mathrm{FES}-\mathrm{CO}_{2}$ for the residential, commercial and institutional sector, the case of the substitution of fossil fuels by solar thermal energy corresponds to the "Methodology for thermal energy projects aimed at reducing fossil fuel consumption in a new or existing installation." In general, the relationship used for the calculation of emissions is Equation 1:

$$
R E_{a}=E E B_{a}-E P_{a}
$$

where $R E_{a}$ is Emission reduction in year "a," $E E B_{a}$ is Emissions associated with the baseline scenario in year "a," and $E P_{a}$ is Project associated emissions in year "a." The "baseline scenario," or reference scenario, depicts the state which exists prior to the implementation of the project activity. The "project scenario" depicts the future state that will exist once the project is running.

In order to calculate the emissions, the following two scenarios are defined for both projects:

- Baseline scenario; the average amount of NG used to produce the needed DHW, in cubic meters, is accessible for the social landlord for the cases analyzed, as well as the efficiency of the system.

- Project scenario; the fraction of fossil fuels substituted by solar thermal energy is also known, as well as the new efficiency of the system, as it can be calculated from the energy study carried out before the tendering of the works.

Initially, DHW needs were produced by boilers running on fossil fuels and they are partially satisfied by renewables after substitution of the solar systems. The physical-chemical constants used to calculate the emissions reduction between the reference and the project scenarios are shown in Table 1.

\section{Renovation of a Building}

The third project analyzed is linked to an integral building renovation (including the physical accessibility), located in San Sebastian (Spain). It is a small multi-occupancy building, of only 13 dwellings, built at the beginning of the twentieth century. The structure of the building is made of wood, with four floors and no elevator, and with a store on the first floor. In spite of not being a building of great constructive or patrimonial value, it is of interest at a conceptual and historical level. A rehabilitation was previously carried out in 1979. The initial plan of demolishing the building was abandoned, but the main part of the dwellings have been empty for a long time. Being such an old building, the renovation up to Nearly Zero-Energy Buildings was unfeasible, although the final energy demand is expected to drop to a level closer to zero emissions. The project includes the placement of insulation on the facades, the replacement of the individual boilers running on NG by a heat pump providing centralized heating, a new ventilation system with heat recovery, and the installation of renewable energies (a small PV installation). The new elevator installed is regenerative, sharing batteries with the solar panels. Since the renovation works started in 2020, it was not possible to include this integral renovation in the "Proyecto Clima" submitted in 2019.

Here, the case of the energy refurbishment of a building pertains to the "Methodology for Energy Efficiency projects aimed at reducing fossil fuel consumption in a building" proposed by FES- $\mathrm{CO}_{2}$. The general equation to apply is the same as in the previous case, Equation 1.

The two scenarios considered to calculate the emissions are the following:

- Baseline scenario; the flow rate of NG consumed is unknown, as many of the dwellings are unoccupied. But the energy needs are taken from the energy study included in the renovation project, including both heating and DHW.

- Project scenario; the new energy needs can be calculated, and the efficiency of the heat pump is known. The new PV system is excluded.

The input data in this case is taken from the energy performance certificates, including the total living area. The physical-chemical constants used are the same-Table 1.

\section{RESULTS}

This section is divided into two sub-sections; the first one concerns the calculations of foreseen emissions reduction exante, whereas the second one corresponds to the prospective verification by a third party.

\section{Calculations Ex-ante}

As explained above, this is the information sent to the FES- $\mathrm{CO}_{2}$ for approval.

\section{Fossil Fuels Substitution by Solar Thermal Energy}

ZABALGANA 92. In the baseline scenario, the energy needs are fully satisfied by a boiler running on NG. The average NG flow rate from 2016 to 2018 consumed by the boiler is $113.164,60$ $\mathrm{m}^{3}$, and using the values in Table 1, this is 4142,75 GJ or $244,2 \mathrm{t}$ $\mathrm{CO}_{2}$ e. The portion spent on DHW is unknown because there is no specific meter for this aim. However, it can be theoretically calculated according to the CTE for multi-occupancy buildings (Ministerio de Vivienda, 2017), if a quantity of 28 liters at a temperature of $60^{\circ} \mathrm{C}$ is considered for each tenant per day. The occupancy can be obtained from the CTE; 1,5 person in dwellings with one bedroom, 3 people with two bedrooms, and 4 with three bedrooms. In ZABALGANA 92, 2 of the dwellings have one room, 27 have two rooms, and the rest have three rooms, summing a total occupancy of 336 people. In the end, a total 
TABLE 2 | NPV and IRR for the installation of the solar thermal system in ZABALGANA 92.

\begin{tabular}{lccccc}
\hline ZABALGANA 92 & $\mathbf{2 0 2 0}$ & $\mathbf{2 0 2 5}$ & $\mathbf{2 0 3 0}$ & $\mathbf{2 0 3 5}$ & $\mathbf{2 0 4 0}$ \\
\hline Without selling the emissions & & & & \\
NPV & $-68376,2$ & $-62081,3$ & $-51209,23$ & $-32431,8$ & 0 \\
IRR & $-0,103531$ & & & & \\
After selling the emissions & & & & \\
NPV & $-68327,45$ & $-61772,48$ & $-50668,92$ & $-31860,44$ & 0 \\
IRR & $-0,10075$ & & & &
\end{tabular}

energy linked to DHW of $154.375 \mathrm{kWh}$. As there is no underconsumption for DHW (Astrain et al., 2019), this is an acceptable estimation of the actual DHW consumption.

In the project scenario, a total of 36 vacuum tubes are placed vertically in the roof, each of them with an equivalent area of 1,51 $\mathrm{m}^{2}$-a total area of $54,36 \mathrm{~m}^{2}$. The technical characteristic of these solar collectors are; an optical performance of 0,752 , a linear loss coefficient of $1,906 \mathrm{~W} /\left(\mathrm{m}^{2} \cdot \mathrm{K}\right)$, and a quadratic loss coefficient of $0,004 \mathrm{~W} /\left(\mathrm{m}^{2} \cdot \mathrm{K}\right)$. The average solar irradiation in Vitoria-Gasteiz in $\mathrm{kWh} / \mathrm{m}^{2}$ is taken from the "Atlas de radiación solar en España" (Atlas of Solar Radiation in Spain) (Ávila et al., 2012). Due to the fact that it is a multi-occupancy building, a centralization factor of 0,75 has to be included (Ministerio de Vivienda, 2017). As a result, the solar thermal collectors provide 150,4 GJ (41.350 $\mathrm{kWh}$ ), which is the $28,4 \%$ of the calculated DHW, and the $3,63 \%$ of the NG consumed by the boiler in the baseline scenario. Hence the total emission reduction due to NG substitution is $9 \mathrm{t} \mathrm{CO}_{2} \mathrm{e}$.

The initial investment, the cost of the solar system installed, is $€ 57,250.00$ w/o VAT. The abatement cost, the ratio between the investment and the emissions reduction, is $€ 57.250,00 \mathrm{w} / \mathrm{VAT} / 9 \mathrm{t} \mathrm{CO}_{2} \mathrm{e}$.

Additionally, every year the following expenses must be added:

- The solar installation consumes $1,000 \mathrm{kWh}$ of electricity. Its price is $€ 0,16$ per $\mathrm{kWh}$, so, $€ 160$,

- Maintenance costs are $€ 1,104-€ 1$ per month per person-.

The main annual savings for the return on investment are fuel savings ( $41.350 \mathrm{kWh} /$ year), which is around $€ 2.067,5$ per yearthe price of the energy being $€ 0,05$ per $\mathrm{kWh}-$.

For this investment, it is possible to calculate the Net present value (NPV) and the Internal rate of return on investment (IRR), shown in Table 2. No corrections for inflation are included, it is supposed that in the EU region inflation is stable and the effects between expenses and revenues are compensated. The calculations are performed for a period of 20 years, the useful life of the solar vacuum tubes, initially without the money obtained after selling the emissions to FES- $\mathrm{CO}_{2}$.

After submitting this "Proyecto Clima" to the FES- $\mathrm{CO}_{2}$, the social landlord can obtain an income. The price of $\mathrm{CO}_{2}$ emissions in 2019 was $€ 9.7 / \mathrm{t} \mathrm{CO}_{2} \mathrm{e}$, so that $9 \mathrm{t} \mathrm{CO}_{2} \mathrm{e}$ accounted for $€$ 87. But, the emissions have to be verified, and the report adds around $€ 100$ to the expenditures. As the report can include all the installations, only half of the cost is charged to ZABALGANA
TABLE 3 | NPV and IRR for the installation of the solar thermal system in ARRASATE 140.

\begin{tabular}{lllllll}
\hline $\begin{array}{l}\text { ARRASATE } \\
140\end{array}$ & 2020 & 2025 & 2030 & 2035 & 2040 & 2045 \\
\hline
\end{tabular}

\begin{tabular}{|c|c|c|}
\hline \multicolumn{3}{|c|}{ Without selling the emissions } \\
\hline NPV & $-45823,33-39124,38-31371,73-22399,64-12016,31$ & 0 \\
\hline $\mathrm{IRR}$ & $-0,029335$ & \\
\hline \multicolumn{2}{|c|}{ After selling the emissions } & \\
\hline NPV & $-45838,72-39205,79-31495,23-22531,96-12112,46$ & 0 \\
\hline $\mathrm{IRR}$ & $-0,03021$ & \\
\hline
\end{tabular}

92, i.e., $€ 50$. In Table 2 , the calculations are repeated with the income obtained from the FES- $\mathrm{CO}_{2}$.

Since 2019 the price of carbon emissions rose dramatically, up to around $€ 50 / \mathrm{t} \mathrm{CO}_{2} \mathrm{e}$ in May 2021. The IRR for that case is $-0,077792$. Even with these high $\mathrm{CO}_{2}$ prices, the investment is not returned.

ARRASATE 140. Concerning the second installation, the baseline scenario is calculated taking into account the gas bills of 2018. The final flow rate of NG consumed by the boiler is $78.370,00 \mathrm{~m}^{3}$, which equals to $2868.98 \mathrm{GJ}\left(169,12 \mathrm{t} \mathrm{CO} \mathrm{CO}_{2} \mathrm{e}\right)$. The theoretical needs for DHW were calculated as in ZABALGANA 92. In ARRASATE 140, 14 of the dwellings have one room, 90 have two rooms, and 36 have three rooms. In the end, this makes a final occupancy of 435 people and a total energy linked to DHW of $145.506 \mathrm{kWh}$.

In the project scenario, a total of 42 solar collectors are placed in the roof, each of them with a total area of $2,51 \mathrm{~m}^{2}$-the total area of all of the collectors totaling $105,42 \mathrm{~m}^{2}$, an optical performance of 0,821 , and a linear loss coefficient of $4,854 \mathrm{~W} /\left(\mathrm{m}^{2} \cdot \mathrm{K}\right)$. The average solar irradiation in Arrasate in $\mathrm{kWh} / \mathrm{m}^{2}$ is known (Ávila et al., 2012), and the same centralization factor is used. So, the solar thermal system provides $221,2 \mathrm{GJ}(60.819 \mathrm{kWh})$, which is the $39,4 \%$ of the calculated DHW. Only the emissions exceeding the compulsory $30 \%$ for solar heating production can be counted, as the project was approved after the new building regulation of 2006: this is $58,8 \mathrm{GJ}(14.510 \mathrm{kWh})$, the $2,05 \%$ of the NG consumed by the boiler in the baseline scenario. Hence the total emission reduction due to NG substitution is $3,5 \mathrm{t} \mathrm{CO}_{2} \mathrm{e}$.

The initial investment of this system is $€ 38.884,00 \mathrm{w} / \mathrm{o}$ VAT, so that the abatement cost is $€ 38.884 \mathrm{w} / \mathrm{VAT} / 3,5 \mathrm{t} \mathrm{CO} \mathrm{CO}_{2}$. The initial investment is annually increased by the electricity consumed by the solar installation, i.e. $1,000 \mathrm{kWh}-€ 160-$, and the maintenance costs, this is $€ 1,700$ applying the same quantity as in ZABALGANA 92.

As in the previous case, the main annual saving for the return on investment is fuel savings-the total produced by the solar system, $60.819 \mathrm{kWh} /$ year-, equal to a total amount of $€ 3,041$ per year-same NG price.

Starting with the analysis without taking into account the revenues from the FES $\mathrm{CO}_{2}$, and assuming that the lifetime of the solar installation is 25 years, the calculations for the NPV and IRR are shown in Table 3.

The sale of emissions is calculated with the same price of $\mathrm{CO}_{2}$, i.e., $3,5 \mathrm{tCO}_{2} \mathrm{e}$ at $€ 9.7 / \mathrm{t} \mathrm{CO}_{2} \mathrm{e}$, which is around $€ 34$. The 
TABLE 4 | NPV and IRR for the installation of the solar thermal system in ITURRITXO.

\begin{tabular}{|c|c|c|c|c|c|c|}
\hline ITURRITXO & 2020 & 2025 & 2030 & 2035 & 2040 & 2045 \\
\hline \multicolumn{7}{|c|}{ Without selling the emissions } \\
\hline NPV & $-480014,86$ & $-427764,13$ & $-359411,18$ & $-269993,77$ & $-153020,41$ & 0 \\
\hline $\mathrm{IRR}$ & $-0,0523084$ & & & & & \\
\hline \multicolumn{7}{|c|}{ After selling the emissions } \\
\hline NPV & $-479675,46$ & $-425835,31$ & $-356258,62$ & $-266345,86$ & $-150153,17$ & 0 \\
\hline IRR & $-0,0499868$ & & & & & \\
\hline \multicolumn{7}{|c|}{ After selling the emissions, taking into account the under consumption ex-ante } \\
\hline NPV & $-479781,23$ & $-426434,84$ & $-357235,85$ & $-267473,44$ & $-151036,92$ & 0 \\
\hline IRR & $-0,0507074$ & & & & & \\
\hline
\end{tabular}

remaining $€ 50$ due to the verification of emissions report has to be included.

Considering the high $\mathrm{CO}_{2}$ prices in 2021, the IRR is $-0,02279$, i.e., the investment is not returned in this case either.

\section{Renovation of a Building}

In the baseline scenario, the calculated energy demand is 279.3 $\mathrm{kWh} / \mathrm{m}^{2} \mathrm{yr}$, including heating and $\mathrm{DHW}$, which correspond with a label $\mathrm{F}$ for energy consumption-E for carbon emissions, $54.2 \mathrm{~kg} \mathrm{CO}_{2} / \mathrm{m}^{2} \mathrm{yr}-$. The living area of all the floors of the building is $774 \mathrm{~m}^{2}$. Taking the same price for the NG, this results in a total amount of $€ 10,805$. The DHW needs, calculated as in the previous cases, is $21369,5 \mathrm{kWh} / \mathrm{yr}$. So, the heating represents the $89 \%, 194.735 \mathrm{kWh} / \mathrm{yr}$. Regarding the emissions, a total amount of $42 \mathrm{tCO} 2 \mathrm{e} ; 37,3 \mathrm{t} \mathrm{CO}_{2} \mathrm{e}$ for heating and $4,6 \mathrm{tCO}_{2} \mathrm{e}$ for DHW.

In the project scenario, the energy demand is $41,8 \mathrm{kWh} / \mathrm{m}^{2} \mathrm{yr}$, so, the energy label is B. The DHW demand is maintained, while the demand for heating is lowered down to $10,996,7 \mathrm{kWh}(14,21$ $\mathrm{kWh} / \mathrm{m}^{2} \mathrm{yr}$ ). The emissions are further reduced thanks to a heat pump, i.e., using electricity instead of NG. The coefficient of performance (COP) of the heat pump is 4,3 , which means that the needed primary energy is 7,527,02 $\mathrm{kWh} / \mathrm{yr}$. The electricity expenses are $€ 840$-electricity price is $€ 0,16$ per $\mathrm{kWh}-$. In order to calculate the emissions for electricity, the coefficient equals to $0,399 \mathrm{~kg} \mathrm{CO} / \mathrm{kWh}$ (Hue $\mathrm{CO}_{2} \mid$ Huella de carbono de la construcción de obras públicas, 2020). The final emissions account for $3 \mathrm{t} \mathrm{CO}_{2} \mathrm{e}$, so that 38,8 t $\mathrm{CO}_{2} \mathrm{e}$ can be sold to $\mathrm{FES}-\mathrm{CO}_{2}$ every year.

For the economic viability study, the new elevator and the PV system are not taken into account. The cost of new facades is $€ 329.740,83$, the cost of the heat pump is $€ 48.400,00$ and its lifetime is 25 years, and the cost of the new ventilation is $€ 110.742,95$. Additionally, maintenance costs are $€ 1,560$. The IRR without taking into account the selling of the emissions is $-0,0523084$, as shown in Table 4 .

When the income from the selling of emissions is taken into account, $€ 376$ minus $€ 33$ of the verification report, the IRR is $-0,0499868$.

In the previous calculations, the baseline scenario does not take into account the under-consumption. As most of the dwellings were not occupied, it is not possible to have a record of actual energy expenses for all the tenants, and the actual under-consumption cannot be calculated. So, the assumption for under-consumption of NG for heating is made based on a study performed with tenants in other buildings (Astrain et al., 2019), which gave a reduction of $30 \%$ of the heating in buildings with individual boilers compared to the theoretical energy performance of the building. As a consequence, the initial emissions would be $30,7 \mathrm{t} \mathrm{CO}_{2}$ e. The assumption for the results after retrofit is that the energy consumed for heating is the average of a consumer without income problems $-3 \mathrm{t} \mathrm{CO}_{2} \mathrm{e}$ do not change. So, the total emissions to be sold are $27,7 \mathrm{t} \mathrm{CO}_{2} \mathrm{e}-$ $€ 269$. Obviously, the IRR in this case is worse, $-0,0507074$, and also at high $\mathrm{CO}_{2}$ prices in 2021 .

\section{Expected Results of the Ex-post Verification}

The emissions reductions must be verified by a third independent party, so, the accounting of emissions is only possible with actual energy consumption after the renovation works are finished.

In the verification after the substitution of fossil fuels by solar thermal energy to produce DHW, as there is no underconsumption for DHW, the emissions ex-post are expected to be average. Ex-ante results are maintained: NPV and IRR are only slightly improved thanks to the selling of the emissions.

In the renovation project of a building, the verification should confirm that energy consumption dedicated to heating in the baseline scenario is lower, and average in the project scenario (Sunikka Blank and Galvin, 2012). So, after renovation works are finished, the verified emissions reduction should be those calculated taking into account under-consumption before renovation $-27,7 \mathrm{t} \mathrm{CO}_{2} \mathrm{e}-$, which would be disadvantageous for the rehabilitation of buildings where low-income tenants live. However, as it is not possible to verify the actual energy consumption before retrofit, the under-consumption cannot be confirmed in this case study.

\section{DISCUSSION}

The main contribution made to addressing gaps in existing knowledge of low carbon regulations is that, when low-income households are involved, before renovation $\mathrm{CO}_{2}$ emissions are lower and therefore those projects are taking less advantage of 
the carbon market. Moreover, targets for $\mathrm{CO}_{2}$ reduction after retrofitting may not be achieved (Teli et al., 2016).

The problem of under-consumption has no effect on the first two cases studied, as the solar systems produce only DHW, and the theoretical estimation of DHW and the actual consumptions are comparable. In none of the first two cases the initial investment is recovered, even in the case of taking into account the increasing price of carbon since 2019 (€ 25/t $\mathrm{CO}_{2} \mathrm{e}$ in 2020, and $€ 50 / \mathrm{t} \mathrm{CO}_{2} \mathrm{e}$ in May 2021). In the third case analyzed, the under-consumption reduces the energy consumed for heating in the baseline scenario by a $30 \%$, so that the benefit of low income from the emissions market is less. The economic viability is also not achieved, even after receiving the amounts corresponding to the emission reductions paid for the "Programa Clima." When FES- $\mathrm{CO}_{2}$ asks for verification of emissions and these are calculated, additional issues may arise.

The subsequent policy recommendation, the ex-ante accounting of $\mathrm{CO}_{2}$ emissions should be justified on the basis of theoretical results with average consumers, rather than verifying before retrofit emissions. In France, a specific subtype within the EE obligations is dedicated to low energy rated buildings housing low income families, regardless of the final verified carbon reductions. If low income households live in performant housing, e.g., recently renovated buildings, their energy bills will continue to be low, but they will be able to keep their homes at a comfortable temperature (Hong et al., 2009). These benefitsindoor air quality and thermal comfort, health, and also employment-should be taken into consideration (Ugarte et al., 2016).

On the key implications for positive energy districts, according to the FES- $\mathrm{CO}_{2}$ methodology in Spain, district heating running on biomass is allowed to account for zero emissions. But it was not until very recently when the first building managed

\section{REFERENCES}

Antepara, I., Papada, L., Gouveia, J. P., Katsoulakos, N., and Kaliampakos, D. (2020). Improving energy poverty measurement in Southern European regions through equivalization of modeled energy costs. Sustainability 12, 1-21. doi: $10.3390 /$ su12145721

Aranda, J., Zabalza, I., Conserva, A., and Millán, G. (2017). Analysis of energy efficiency measures and retrofitting solutions for social housing buildings in spain as a way to mitigate energy poverty. Sustainability 9:1869. doi: 10.3390/su9101869

Astrain, P., Orbea, C., Sagasti, G., Antepara, I., Hidalgo Betanzos, J., and Hernandez, P. (2019). Plan Zero plana: alta eficiencia en alquiler público. in (Madrid). Available online at: https://www.construible.es/comunicaciones/ comunicacion-plan-zero-plana-alta-eficiencia-alquiler-publico.

Ávila, J. M. S., Martín, J. R., Alonso, C., Cos, M. del C. S. de, Cadalso, J. M., and Bartolom,é, M. L. (2012). Atlas de radiación solar en España utilizando datos del SAF de clima de EUMETSAT. in (Biblioteca AEMET). Available online at: https:/www.aemet.es/documentos/es/serviciosclimaticos/ datosclimatologicos/atlas_radiacion_solar/atlas_de_radiacion_24042012.pdf.

Barnes, M., and McKnight, A. (2014). Understanding the Behaviours of Households in Fuel Poverty: A Review of Research Evidence. Available online at: http:// openaccess.city.ac.uk/id/eprint/14443.

Boardman, B. (2013). Fixing Fuel Poverty: Challenges and Solutions. New York, NY: Routledge. by Alokabide was renovated and connected to a new centralized heating system running on biomass at a district level. On the contrary, PV at a district level-i.e., solar energy communities, which are easier to implement, are excluded. So, this also reduces the potential for emission reductions.

Another conclusion is that, taking into account the low energy consumption of social tenants, decarbonization in the social housing sector is easier to achieve than the reduction of the energy consumed. $\mathrm{CO}_{2}$ emissions reductions can be achieved if a part (or the whole) of the primary energy provided by fossil fuels is substituted by renewable energies. In the third case analyzed, this is achieved thanks to heat pumps (Owen et al., 2013).

\section{DATA AVAILABILITY STATEMENT}

The original contributions presented in the study are included in the article, further inquiries can be directed to the corresponding author.

\section{AUTHOR CONTRIBUTIONS}

The author confirms being the sole contributor of this work and has approved it for publication.

\section{ACKNOWLEDGMENTS}

The author would like to thank Alokabide for access to the data. The author would like to thank Unai Castro for the proofreading of the first draft, and Arabako Campuseko Hizkuntza Laborategia (Language Laboratory at the campus of Alava) for the proofreading of the reviewed version. The author would like to thank the editor and the reviewers for their comments that helped to improve the manuscript.
European Commission (2020). Communication From the Commission to the European Parliament, The Council, The European Economic and Social Committee and The Committee of the Regions A Renovation Wave for Europegreening our buildings, creating jobs, improving lives COM/2020/662 final. Available online at: https://eur-lex.europa.eu/legal-content/EN/TXT/HTML/? uri=CELEX:52020DC0662andfrom=EN (accessed October 23, 2020).

European Parliament (2013). European Parliament Resolution of 11 June 2013 on Social Housing in the European Union (2012/2293(INI)). Official Journal of the European Union. Available online at: https://eur-lex.europa.eu/legal-content/ EN/TXT/HTML/?uri=CELEX:52013IP0246andfrom=EN (accessed October $24,2020)$.

Hathway, K. (2010). Community Power Empowers. Urban Forum Available online at: https://www.wcmt.org.uk/sites/default/files/migrated-reports/687_1.pdf

Hearn, A. X., Sohre, A., and Burger, P. (2021). Innovative but unjust? analysing the opportunities and justice issues within positive energy districts in Europe. Energy Res. Soc. Sci. 78:102127. doi: 10.1016/j.erss.2021. 102127

Hernández, P., Hidalgo Betanzos, J., García, C., Fernández, J. and Flores, I. (2019). A comparison between predicted and measured energy use in social housing. in (Vitoria-Gasteiz (Spain)). Available at: https://web-argitalpena.adm.ehu.es/lista productos.asp?IdProducts=UCPDF 190860\&titulo=Transition.\%2010th\%20Eu ropean $\% 20$ Conference $\% 20$ on $\% 20$ Energy $\% 20$ Efficiency $\% 20$ and $\% 20$ Sustainabi lity\%20in\%20Architecture\%20and\%20Planning\%20\%96\%203rd\%20Internatio nal\%20Congress\%20on\%20Advanced\%20Construction\# 
Hong, S. H., Gilbertson, J., Oreszczyn, T., Green, G., and Ridley, I. (2009). A field study of thermal comfort in low-income dwellings in England before and after energy efficient refurbishment. Build. Environ. 44, 1228-1236. doi: 10.1016/j.buildenv.2008. 09.003

Hue $\mathrm{CO}_{2}$ | Huella de carbono de la construcción de obras públicas (2020). Available online at: http://hueco2.tecniberia.es/ (accessed November 29, 2020).

Jenkins, D., Middlemiss, L., and Pharoah, R. (2011). A Study of Fuel Poverty and Low-Carbon Synergies in Social Housing. UKERC Available online at: http:// eprints.whiterose.ac.uk/79391/.

Ministerio de Vivienda (2017). Código Técnico de la Edificación. Documento Básico HE. Ahorro de energía. Available online at: https://www.codigotecnico.org/ images/stories/pdf/ahorroEnergia/DBHE.pdf.

Ministerio para la Transición Ecológica y el Reto Demográfico (2019). Metodologías para la estimación de la Reducción de Emisiones de los Proyectos Clima (calculo ex-ante). Available online at: https://www.miteco.gob.es/es/ cambio-climatico/temas/fondo-carbono/metodologias.aspx (accessed October 24, 2020).

Moore, R. (2012). Definitions of fuel poverty: Implications for policy. Energy Policy 49, 19-26. doi: 10.1016/j.enpol.2012.01.057

Owen, A., Mitchell, G., and Unsworth, R. (2013). Reducing carbon, tackling fuel poverty: adoption and performance of air-source heat pumps in East Yorkshire, UK. Local Environ. 18, 817-833. doi: 10.1080/13549839.2012.732050

Rademaekers, K., Yearwood, J., Ferreira, A., Pye, S., Hamilton, I., Agnolucci, P., et al. (2016). Selecting Indicators to Measure Energy Poverty. Available online at: https://ec.europa.eu/energy/sites/ener/files/documents/Selecting \%20Indicators\%20to\%20Measure\%20Energy\%20Poverty.pdf

Rosenow, J., Platt, R., and Flanagan, B. (2013). Fuel poverty and energy efficiency obligations-A critical assessment of the supplier obligation in the UK. Energy Policy 62, 1194-1203. doi: 10.1016/j.enpol.2013.07.103

Sunikka Blank, M., and Galvin, R. (2012). Introducing the prebound effect: the gap between performance and actual energy consumption. Build. Res. Inform. 40, 260-273. doi: 10.1080/09613218.2012.690952
Teli, D., Dimitriou, T., James, P. A. B., Bahaj, A. S., Ellison, L., and Waggott, A. (2016). Fuel poverty-induced 'prebound effect' in achieving the anticipated carbon savings from social housing retrofit. Build. Serv. Eng. Res. Technol.37, 176-193. doi: 10.1177/0143624415621028

Ugarte, S., van der, R. E. E., B., Voogt, M., Eichhammer, W., Ordoñez, J. A., et al. (2016). Energy Efficiency for Low-Income Households. Policy Department A: Economic and Scientific Policy, European Parliament. Available online at: http://www.europarl.europa.eu/thinktank/en/document.html?reference= IPOL_STU(2016)595339.

Walker, G. (2008). Decentralised systems and fuel poverty: are there any links or risks? Energy Policy 36, 4514-4517. doi: 10.1016/j.enpol.2008. 09.020

Wilde, P. (2014). The gap between predicted and measured energy performance of buildings: a framework for investigation. Autom. Constr. 41, 40-49. doi: 10.1016/j.autcon.2014.02.009

Conflict of Interest: The author declares that the research was conducted in the absence of any commercial or financial relationships that could be construed as a potential conflict of interest.

Publisher's Note: All claims expressed in this article are solely those of the authors and do not necessarily represent those of their affiliated organizations, or those of the publisher, the editors and the reviewers. Any product that may be evaluated in this article, or claim that may be made by its manufacturer, is not guaranteed or endorsed by the publisher.

Copyright (c) 2021 Antepara. This is an open-access article distributed under the terms of the Creative Commons Attribution License (CC BY). The use, distribution or reproduction in other forums is permitted, provided the original author(s) and the copyright owner(s) are credited and that the original publication in this journal is cited, in accordance with accepted academic practice. No use, distribution or reproduction is permitted which does not comply with these terms. 